\title{
High Concentration of L-Arginine Suppresses Nitric Oxide Synthase Activity and Produces Reactive Oxygen Species in NB9 Human Neuroblastoma Cells
}

\author{
Sachiko Todoroki, ${ }^{1,2}$ Shinji Goto, ${ }^{1}$ Yoshishige Urata, ${ }^{1}$ \\ Kazuki Komatsu, ${ }^{1}$ Koji Sumikawa, ${ }^{2}$ Tsutomu Ogura, ${ }^{3}$ \\ Ichiro Matsuda, ${ }^{4}$ and Takahito Kondo ${ }^{1}$
}

${ }^{1}$ Department of Biochemistry and Molecular Biology in Disease, Atomic Bomb Disease Institute, Nagasaki University School of Medicine, Nagasaki, Japan

${ }^{2}$ Department of Anesthesiology, Nagasaki University School of Medicine, Nagasaki, Japan

${ }^{3}$ Division of Cancer Therapy Development, National Cancer Institute, Chiba, Japan

${ }^{4}$ Department of Pediatrics, Kumamoto University School of Medicine, Kumamoto, Japan

Communicated by E. Buetler. Accepted June 11, 1998.

\begin{abstract}
Hereditary argininemia manifests as neurological disturbance and mental retardation, features not observed in other amino acidemias. The cytotoxic effect of a high concentration of L-arginine ( $\mathrm{L}$-Arg) was investigated using NB9 human neuroblastoma cells (NB9), which express neuronal nitric oxide synthase (nNOS). When the concentration of L-Arg in the medium increased from 50 $\mu \mathrm{M}$ to $2 \mathrm{mM}$ after incubation for $48 \mathrm{hr}$, the intracellular concentration of L-Arg increased from $68.0 \pm 1 \mathrm{pmol} /$ $10^{6}$ cells to $1310.0 \pm 5 \mathrm{pmol} / 10^{6}$ cells and that of Lcitrulline (L-Cit) from undetectable levels to $47.1 \pm 0.2$ $\mathrm{pmol} / 10^{6}$ cells (mean \pm SD of three independent analyses). This increase in intracellular L-Arg levels caused a decrease in NOS activity by approximately $71 \%$. Flow cytometric analysis showed that reactive oxygen species
\end{abstract}

(ROS) are produced in NB9 exposed to $2 \mathrm{mM} \mathrm{L}$-Arg. The production of ROS was abolished by a NOS inhibitor, $\mathrm{N}^{\mathrm{G}}$-nitro-L arginine-methylester. Production of ROS was also observed when NB9 were treated with L-Cit for 48 hr. To investigate the effect of L-Cit on the activity of NOS, a kinetic study on nNOS was conducted using cellular extracts from NB9. The apparent $K_{m}$ value of nNOS for L-Arg was $8.4 \mu \mathrm{M}$, with a $\mathrm{V}_{\max }$ value of 8.2 $\mathrm{pmol} / \mathrm{min} / \mathrm{mg}$ protein. L-Cit competitively inhibited NOS activity, as indicated by an apparent $K_{i}$ value of $65 \mathrm{nM}$. These results suggest that L-Cit formed by $\mathrm{nNOS}$ in LArg-loaded neuronal cells inhibits NOS activity and $\mathrm{nNOS}$ in these L-Arg-loaded cells functions as a NADPH oxidase to produce ROS, which may cause neurotoxicity in argininemia.

\section{Introduction}

Argininemia (McKusick 20780) is an autosomal recessive disorder caused by a deficiency in the liver-type arginase enzyme (EC 3.5.3.1). The clinical manifestations of argininemia are mental

Address correspondence and reprint requests to: Dr. Takahito Kondo, Department of Biochemistry and Molecular Biology in Disease, Atomic Bomb Disease Institute, Nagasaki University School of Medicine, 1-12-4 Sakamoto, Nagasaki 852-8523, Japan. Phone: 81-95-849-7097; Fax: 81-95-849-7100; E-mail: kondo@net.nagasaki-u.ac-jp retardation, progressive loss of psychomotor functions, spastic tetraplegia (more severe in lower limbs), hyperactivity of deep-tendon reflexes, seizures, and failure to grow (1).

Clinical features of urea-cycle diseases other than argininemia are generally related to multiple episodes of hyperammonemia. However, the concentration of ammonium in plasma is only slightly elevated in most patients with argininemia (2). Neurological symptoms such as a marked degree of spastic diplegia have not been 
described as a regular feature in hyperammonemias associated with other defects in the urea cycle. These neurological manifestations can be progressive even when concentrations of plasma ammonium are within normal levels. This means that hyperammonemia is not the sole factor related to neurological damage in these patients. Elevated concentrations of plasma L-arginine (LArg) or its five catabolites seem to be directly linked to the neurological symptoms seen in these patients (3).

Human liver-type arginase catalyzes the hydrolysis of L-Arg at the last step in urea synthesis, producing urea and ornithine. In 1987, we isolated the complete cDNA of human liver-type arginase (4). This enzyme consists of 322 amino acid residues with a molecular mass of 34,732 daltons (4). The arginase gene is $11.5 \mathrm{~kb}$ long, includes eight exons (5), and has been assigned to chromosome band 6q23 (6).

We have indicated a possible correlation between genotypes and differences in clinical responses to dietary treatment in 11 patients with argininemia. Differences in the degree of clinical improvement during dietary treatment seemed to relate to the nature of the mutations (2).

Furthermore, we have detected three mutations-a nonsense mutation in exon 4, a missense mutation in exon 7 , and a frameshift mutation in exon 8. These mutations are different from those previously reported in the arginase gene (7). Arginase deficiency is apparently genetically heterogeneous (8). We tentatively conclude that argininemia is heterogeneous, at the molecular level (2). The features of this disease are generally progressive. Argininemia is thought to be more closely linked to neurological damage than is hyperammonemia (1). However, the mechanisms by which progressive neural disorders occur are not understood.

L-Arg is converted inside the cells to L-citrulline (L-Cit) by the catalytic reaction of nitric oxide synthase (NOS) (9). There are three isoforms of NOS, designated as endothelial NOS (eNOS), neuronal NOS (nNOS), and inducible NOS (iNOS). The first two isoforms are constitutive and activated through calmodulin-mediated signals. eNOS is present in endothelial cells and the NO synthesized in these cells functions as a vascular relaxation factor. $\mathrm{nNOS}$ is present in neurological cells and the NO synthesized in these cells is believed to play a role in neurotransmission or neurological cytotoxicity. iNOS is present in macrophages, mesangium cells, and glial cells. This enzyme is expressed only when the cells are exposed to cytokines or other stimulants.
It is believed that there is a Cit-NO cycle composed of NOS, argininosuccinate synthetase, and argininosuccinate lyase (10). This means NOS is located among the urea cycle composed of carbamoylphosphate synthetase, ornithine transcarbamylase, argininosuccinate synthetase, argininosuccinate lyase, and arginase. NOS may be regulated by the Cit-NO cycle and the urea cycle. However, the effect of high concentrations of arginine due to arginase deficiency on the Cit-NO cycle has yet to be elucidated.

In the present study, we examined the NO metabolism in neuroblastoma cells at high concentrations of L-Arg. We found that the L-Cit formed by NOS on exposure of the cells to a high concentration of L-Arg competitively inhibits NOS activity and produces reactive oxygen species (ROS). This mechanism may contribute to neural cytotoxicity in argininemia.

\section{Materials and Methods}

\section{Chemicals}

RPMI1640 was purchased from GIBCO BRL (Gaithersburg, MD). Human neuroblastoma cells (NB9 and IMR32) were donated by the Japanese Cancer Research Resources Bank (Tokyo, Japan). $\mathrm{N}^{\mathrm{G}}$-nitro-L-arginine methylester (L-NAME) was from Wako Pure Chemical Industries (Osaka, Japan).

\section{Cell Culture}

NB9 and IMR32 were maintained in SelectAmine RPMI 1640 (GIBCO BRL), which contains essential amino acids except L-Arg, and were supplemented with $50 \mu \mathrm{M} \mathrm{L}-\mathrm{Arg}$ and $15 \%$ fetal calf serum (FCS) at $37^{\circ} \mathrm{C}$ in $5 \% \mathrm{CO}_{2}$ with $100 \%$ humidity. The cells were harvested and collected by centrifugation at $4^{\circ} \mathrm{C}$ for $3 \mathrm{~min}$ at $200 \times g$. The cytosolic fraction of the cells was recovered by lysis via the addition of 4 volumes of $10 \mathrm{mM} \mathrm{NaH}{ }_{2} \mathrm{PO}_{4} / \mathrm{Na}_{2} \mathrm{HPO}_{4}, \mathrm{pH} 7.4$, containing $0.5 \mathrm{mM}$ EDTA, $0.1 \mathrm{mM} 2$-mercaptoethanol, and $0.5 \mathrm{mM}$ phenylmethylsulfonyl fluoride (PMSF), followed by sonication for $2 \mathrm{~min}$. The cellular debris was removed by centrifugation at $4^{\circ} \mathrm{C}$ for $10 \mathrm{~min}$ at $5000 \times \mathrm{g}$. The cytosolic fraction was employed for the estimation of enzyme activities.

\section{Preparation of $C D N A$}

Cloning of human nNOS, iNOS, and eNOS was performed using the reverse transcriptase-poly- 
merase chain reaction (RT-PCR) method. Template RNA was prepared using RNeasy mini-kits (Qiagen, Hilden, Germany) from NB9 for nNOS and iNOS, and from human umbilical endothelial cells (ECV304) for eNOS. The authentic sense primer for nNOS was 5'-CACGTGGTCCTCATTCTGAG $-3^{\prime}$ and the antisense primer was $5^{\prime}$ TCTCTGTCCACCTGGATTCC- $3^{\prime}$. The authentic sense primer for iNOS was 5'-GTGAGGATCAAAAACTGGGG- $3^{\prime}$ and the antisense primer was 5'-ACCTGCAGGTTGGACCAC-3'. The authentic sense primer for eNOS was 5'-CACTGAGATCGGCACGAGGA- $3^{\prime}$ and the antisense primer was 5'-GTCACCATCGTGGACCACCA-3'. RT-PCR for the preparation of CDNA was performed using these primers and RNA PCR kit (Takara, Tokyo, Japan). The cDNAs obtained were of 455 base pairs corresponding to bp 274728 of human nNOS, 380 base pairs corresponding to bp 459-838 of human iNOS, and 186 base pairs corresponding to bp 1099-1284 of human eNOS. Subcloning for these cDNA was performed using the TA cloning kit (In Vitrogen, San Diego, CA) and the products were used as complementary oligonucleotide probes. These probes were radiolabeled with ${ }^{32} \mathrm{P}$ using a Random Primer DNA Labeling Kit (Takara).

\section{$R T-P C R$}

RT-PCR for the estimation of the levels of NOS mRNA was performed using an RNA PCR kit and a PC-700 program temp control system (Astec, Fukuoka, Japan) with 23 cycles. The level of $\beta$-actin was used as an internal standard. The products of RT-PCR were subjected to electrophoresis in $1 \%$ agarose gels, subsequently transferred to nylon-membrane filters, and later hybridized with ${ }^{32} \mathrm{P}$-labeled probes for NOS isoforms. Autoradiographed filters were analyzed using a Fujix Bio-Analyzer BAS-2000 (Fuji Photo Film, Tokyo, Japan).

\section{Preparation of Nuclear Extracts}

Nuclei extracts were prepared as described previously (11). Briefly, the cells were suspended in hypotonic buffer, $10 \mathrm{mM}$ HEPES, $\mathrm{pH} 7.9$, containing $1.5 \mathrm{mM} \mathrm{MgCl}_{2}, 10 \mathrm{mM} \mathrm{KCl}, 0.2 \mathrm{mM}$ PMSF, and $0.5 \mathrm{mM}$ dithiothreitol (DTT). The swollen cells were homogenized and the nuclei were pelleted by centrifugation at $500 \times g$ for 1 min at $4^{\circ} \mathrm{C}$. Gentle drop-wise addition of a highsalt buffer, $20 \mathrm{mM}$ HEPES, pH 7.9, containing $25 \%$ glycerol, $1.5 \mathrm{mM} \mathrm{MgCl}, 1.2 \mathrm{M} \mathrm{KCl}, 0.2$ mM EDTA, $0.2 \mathrm{mM}$ PMSF, and $0.5 \mathrm{mM}$ DTT, released the soluble proteins from the nuclei. The soluble nuclear extract was prepared by removing precipitable proteins by centrifugation.

\section{Electrophoretic Mobility Shift Assay}

The electrophoretic mobility shift assay for AP-1 was performed as described by Sen and Baltimore (12) with a slight modification. Briefly, nuclear extracts were incubated with an AP-1specific ${ }^{32} \mathrm{P}$-oligonucleotide. The binding reaction proceeded in a $25-\mu$ l volume containing 10 $\mu \mathrm{g}$ of nuclear extract, $5 \mu \mathrm{l}$ of a binding buffer (10 $\mathrm{mM}$ Tris, $\mathrm{pH} 7.5,50 \mathrm{mM} \mathrm{NaCl}, 1 \mathrm{mM}$ EDTA, 1 $\mathrm{mM}$ DTT, $4 \%$ glycerol), and labeled oligonucleotide (3000-6000 cpm). After a 20-min binding reaction at room temperature, samples were loaded on a $6 \%$ nondenaturing polyacrylamide gel and subjected to electrophoresis in $25 \mathrm{mM}$ Tris, $22.5 \mathrm{mM}$ borate, and $0.25 \mathrm{mM}$ EDTA, pH 8.0. For the specificity control, a 100 -fold excess of unlabeled probe was applied. The binding site for the AP-1 probe contained '5-TGATTCA-3'. The DNA binding activity of the extracts was quantified by estimating the amount of the ${ }^{32} \mathrm{P}$ labeled AP-1.

\section{Estimation of NOS Activity}

Accumulated nitrite levels in the cell culture medium were determined as change in the absorbance at $540 \mathrm{~nm}$ using an automated NO detector-HPLC system (ENO-10, Eicom, Kyoto, Japan). The activity of NOS was estimated by measuring the formation of $\mathrm{L}-\left[\mathrm{U}-{ }^{14} \mathrm{C}\right]-\mathrm{Cit}$ from $\mathrm{L}-\left[\mathrm{U}-{ }^{14} \mathrm{C}\right]$-Arg using a Dowex-50W column according to the methods described by Galea et al. (13). In these experiments, $10 \mu \mathrm{l}$ of sample, corresponding to the cell extract from $1 \times 10^{6}$ cells, was incubated at $37^{\circ} \mathrm{C}$ in the presence of $50 \mathrm{mM}$ HEPES-NaOH, pH 7.8, $1 \mathrm{mM} \mathrm{NADPH}, 10 \mu \mathrm{M}$ FAD, $7 \mu \mathrm{g}$ of calmodulin (Sigma), various concentrations of L-Arg, and L-[U-C $\left.{ }^{14}\right]$-Arg (305 $\mathrm{mCi} / \mathrm{mmol}$ ) to obtain a specific activity of 20 $\mathrm{fmol} / \mathrm{dpm}$ in a total volume of $100 \mu \mathrm{l}$.

\section{Estimation of Production of ROS}

The production of intracellular ROS induced by incubating the cells with a high concentration of L-Arg was estimated flow cytometrically using 2'7-dichlorofluorescein-diacetate (DCFHDA) as a substrate according to the method of Bass et al. (14). NB9 $\left(1 \times 10^{6}\right)$ incubated with $50 \mu \mathrm{M}$ or $2 \mathrm{mM} \mathrm{L}$-Arg for $48 \mathrm{hr}$ was suspended in phosphate-buffered saline (PBS; 1 part 0.1 
Table 1. Levels of L-Arg and L-Cit

\begin{tabular}{|c|c|c|c|c|}
\hline \multirow[b]{2}{*}{ Cells } & \multirow[b]{2}{*}{ Medium } & \multicolumn{2}{|c|}{ Intracellular } & \multirow[b]{2}{*}{$\begin{array}{c}\text { NOS Activity } \\
(\%)\end{array}$} \\
\hline & & L-Arg & L-Cit & \\
\hline \multirow[t]{2}{*}{ NB9 } & $50 \mu \mathrm{M} L-A r g$ & $68.0 \pm 1.0$ & N.D. & 100 \\
\hline & $2 \mathrm{mM}$ L-Arg & $1310.0 \pm 5.0 *$ & $47.1 \pm 0.2$ & $71.0 \pm 4.8^{\star *}$ \\
\hline \multirow[t]{2}{*}{ IMR32 } & $50 \mu \mathrm{M} L-A r g$ & $88.4 \pm 2.1$ & N.D. & $129.0 \pm 14.5$ \\
\hline & $2 \mathrm{mM}$ L-Arg & $1467.2 \pm 10.0^{*}$ & $51.2 \pm 0.5$ & $72.6 \pm 9.7^{* *}$ \\
\hline
\end{tabular}

Cells were treated with $50 \mu \mathrm{M}$ or $2 \mathrm{mM} \mathrm{L-Arg}$ for $48 \mathrm{hr}$.

Values are expressed as mean $\pm \mathrm{SD}$ of three independent analyses.

${ }^{\star} p<0.001,{ }^{* \star} p<0.005$, significantly different from $50 \mu \mathrm{M} \mathrm{L}-\mathrm{Arg}$.

N.D., not detectable.

$\mathrm{M} \mathrm{NaH} \mathrm{PO}_{4} / \mathrm{Na}_{2} \mathrm{HPO}_{4}, \mathrm{pH} 7.4$, and 9 parts $0.154 \mathrm{M} \mathrm{NaCl}$ ) containing $2 \%$ FCS. Then cells were incubated with $5 \mu \mathrm{M}$ DCFH-DA for 30 $\min$ at $37^{\circ} \mathrm{C}$. The formation of $2^{\prime} 7$-dichlorofluorescein was determined by flow cytometry using a FACScan flow cytometer (BectonDickinson, San Jose, CA). The excitation wavelength was $488 \mathrm{~nm}$, and green fluorescent collected through a 530-nm band-pass filter was measured on a logarithmic scale. The formation of ROS was expressed as the fluorescence intensity. In another experiment, the cells previously incubated with L-Arg for $48 \mathrm{hr}$ were treated with $2 \mu \mathrm{M}$ dihydrorhodamine 123 (DHR) for $30 \mathrm{~min}$ at $37^{\circ} \mathrm{C}$, and the formation of rhodamine 123 was estimated flow cytometrically as for DCFH-DA.

\section{Amino Acid Analysis}

The intracellular concentration of L-Arg and LCit was estimated using an amino acid analyzer (JLC-300; JOEL, Tokyo, Japan).

\section{Analysis of Nuclear DNA}

DNA damage due to the high concentration of L-Arg was determined by flow cytometry on the basis of formation of sub-Gl phase DNA as described by Gong et al. (15). NB9 was washed with PBS and fixed with $70 \%$ ethanol for $12 \mathrm{hr}$ at $-20^{\circ} \mathrm{C}$ then centrifuged and further incubated with citrate-phosphate buffer ( 1 vol of $0.1 \mathrm{M}$ citric acid and $24 \mathrm{vol}$ of $0.2 \mathrm{M} \mathrm{Na}_{2} \mathrm{HPO}_{4}$ ) for 15 min at $25^{\circ} \mathrm{C}$. The DNA content per nucleus was evaluated flow cytometrically by the addition of propidium iodide to stain nuclei.

\section{Statistical Analysis}

The data are given as the mean \pm SD. Differences were calculated with the Student's $t$-test.

\section{Results}

\section{Activity of NOS}

In the preliminary study, the effect of L-Arg concentration in the medium on NO production was estimated. The NO production in NB9 increased in a linear-dependent manner when the L-Arg concentration ranged from $50 \mu \mathrm{M}$ to $500 \mu \mathrm{M}$, then declined with higher L-Arg concentrations (data not shown). To elucidate the effect of a shift in concentration of L-Arg on NOS activity, the concentration of L-Arg in the medium was increased from $50 \mu \mathrm{M}$ to $2.0 \mathrm{mM}$ and the cells were incubated for $48 \mathrm{hr}$. The NO activity was suppressed by approximately $71 \%$ in $2 \mathrm{mM}-\mathrm{L}-$ Arg-loaded NB9 and $56 \%$ in $2 \mathrm{mM}$-L-Arg-loaded IMR32. (Table 1).

\section{Levels of L-Arg and L-Cit}

Table 1 shows the intracellular levels of L-Arg and L-Cit. When the concentration of L-Arg in the medium was changed from $50 \mu \mathrm{M}$ to $2 \mathrm{mM}$ and the culture incubated for $48 \mathrm{hr}$, the intracellular concentration of L-Arg in NB9 increased from $68.0 \pm 1.0 \mathrm{pmol} / 10^{6}$ cells to $1310.0 \pm 5 \mathrm{pmol} / 10^{6}$ cells and that of $\mathrm{L}$-Cit from undetectable levels to $47.1 \pm 0.2 \mathrm{pmol} /$ $10^{6}$ cells (mean $\pm \mathrm{SD}$ of three independent analyses). A similar change in the levels of L-Arg and L-Cit was observed in L-Arg-loaded 


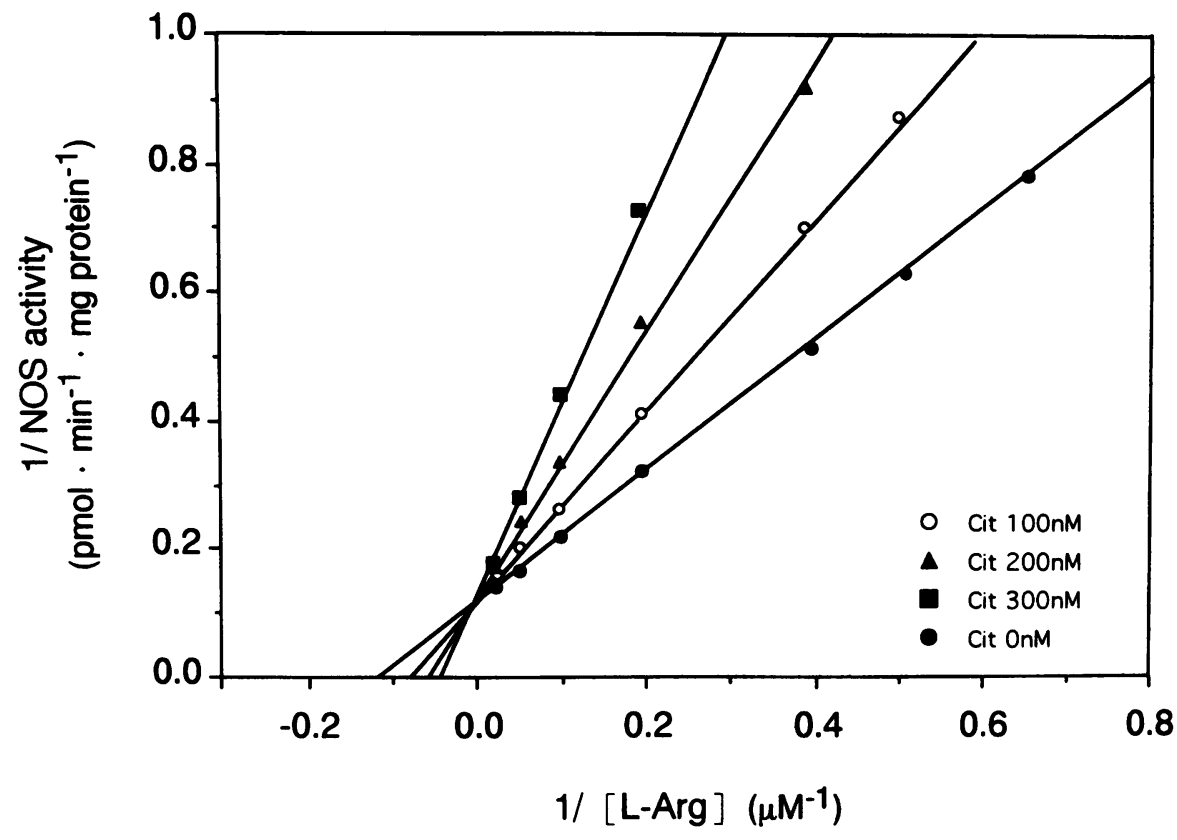

Fig. 1. A kinetic study of nNOS. The effect of L-Arg and L-Cit on NOS activity was estimated. Cellular extract of NB9 was treated with various concentrations of radiolabeled L-Arg and the formation of radiolabeled L-Cit was estimated by scintillation counter as described in Materials and Methods. The formation of L-Cit was expressed as $\mathrm{pmol} / 10^{6}$ cells. The effect of L-Cit on NOS activity was also estimated.
IMR32. These levels remained unchanged for $72 \mathrm{hr}$ (data not shown).

\section{Kinetic Study}

To investigate whether suppression of NO activity is dependent on intracellular levels of L-Cit, kinetic experiments were conducted using cellular extracts from NB9. The effect of L-Cit on NOS activity was determined by estimating the formation of $\mathrm{L}-\left(\mathrm{C}^{14}\right)$-Cit from $L-\left(C^{14}\right)$-Arg. Figure 1 shows the results of a kinetic study on NOS. In this experiment, the L-Arg added ranged from $1.5 \mu \mathrm{M}$ to $50 \mu \mathrm{M}$; at these concentrations, NOS activity was dependent on L-Arg. The apparent $K_{m}$ value of NOS for L-Arg was $8.4 \mu \mathrm{M}$, with a $V_{\max }$ value of 8.2 $\mathrm{pmol} / \mathrm{min} / \mathrm{mg}$ protein. The inhibitory effect of L-Cit on NOS activity was also studied. L-Cit competitively inhibited NOS activity, resulting in an apparent $K_{i}$ value of $65 \mathrm{nM}$.

The effect of an addition of L-Cit to NB9 on NOS activity and cell viability was then studied. As shown in Table 2, addition of L-Cit and incubation for $48 \mathrm{hr}$ increased intracellular levels of L-Cit, inhibited NOS activity, and decreased cell viability in a dose-dependent manner. Elevation of intracellular levels of L-Cit and a decrease in NOS activity were in good agreement with the data shown in Table 1.

\section{The Formation of ROS}

Figure 2 shows the results of flow cytometric analysis of the formation of ROS. Formation of
ROS increased in NB9 incubated with $2 \mathrm{mM}$ L-Arg for $48 \mathrm{hr}$ relative to control: there were 35 versus 13 ROS (relative fluorescence intensity) (Fig. 2, lanes 1 and 2) when estimated with DCFH-DA (Fig. 2A). The formation of ROS also increased in the L-Arg-loaded cells when estimated with DHR: there were 300 versus 60 ROS (relative fluorescence intensity) on the same lanes (Fig. 2B). It remains to be determined whether the ROS formed in these cells are related to NOS.

To establish whether the formation of ROS is related to the Cit-NO cycle, the cells were incu-

Table 2. Effect of L-Cit on NOS activity

\begin{tabular}{llcc}
\hline & & \multicolumn{2}{c}{ Intracellular } \\
\cline { 3 - 4 } Cells & Medium & $\begin{array}{c}\text { L-Cit (pmol/106 } \\
\text { cells) }\end{array}$ & $\begin{array}{c}\text { NOS } \\
\text { activity (\%) }\end{array}$ \\
\hline NB9 & L-Cit $0 \mu \mathrm{M}$ & N.D. & 100 \\
& $50 \mu \mathrm{M}$ & $25.0 \pm 1.0$ & $63.3 \pm 1.1^{*}$ \\
& $100 \mu \mathrm{M}$ & $82.1 \pm 1.5$ & $56.7 \pm 1.2^{\star}$ \\
$250 \mu \mathrm{M}$ & $97.0 \pm 0.9$ & $37.2 \pm 0.8^{*}$ \\
$500 \mu \mathrm{M}$ & $108.1 \pm 1.0$ & $35.2 \pm 1.3^{*}$
\end{tabular}

Cells were treated with various concentrations of $\mathrm{L}$-Cit in the presence of $50 \mu \mathrm{M} \mathrm{L}$-Arg for $48 \mathrm{hr}$.

Values are mean $\pm \mathrm{SD}$ of three independent analyses.

${ }^{*} p<0.005$, significantly different from $0 \mu \mathrm{M} \mathrm{L}$-Cit. N.D., not detectable. 
(A)
(1)

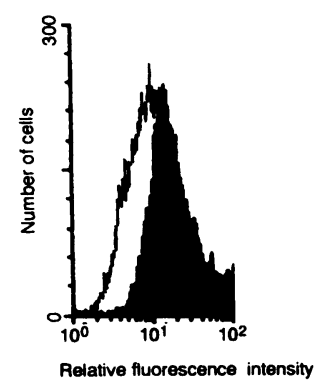

(B)

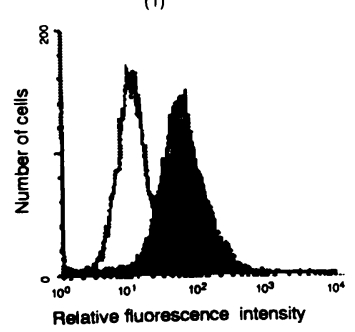

(2)

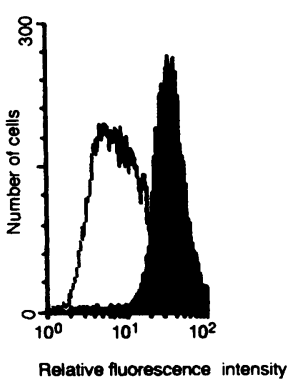

(2)

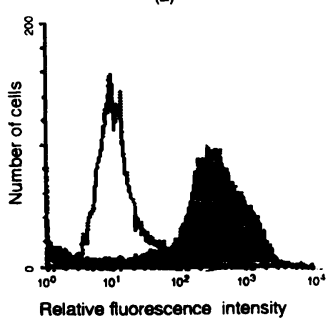

Fig. 2. Intracellular formation of ROS. Fluorescence distribution of DCFH-DA oxidation or DHR oxidation was estimated by flow cytometry in NB9 exposed to $2 \mathrm{mM}$ L-Arg. Lane 1, control $(50 \mu \mathrm{M}$ LArg); lane 2, $2 \mathrm{mM} \mathrm{L-Arg;} \mathrm{lane} \mathrm{3,} 2 \mathrm{mM} \mathrm{L-Arg}$ and 5 mM L-NAME; lane 4, $50 \mu \mathrm{M}$ L-Arg and $250 \mu \mathrm{M} \mathrm{L-}$ Cit. (A) NB9 was incubated for $48 \mathrm{hr}$ as described above, then with $5 \mu \mathrm{M}$ DCFH-DA for $30 \mathrm{~min}$ at $37^{\circ} \mathrm{C}$, and the formation of DCFH-DA oxidation was

bated with $2 \mathrm{mM} \mathrm{L}$-Arg for $48 \mathrm{hr}$ in the presence of L-NAME. The production of ROS was abolished by L-NAME (Fig. 2, lane 3). Furthermore, incubation of the cells with $250 \mu \mathrm{M} \mathrm{L}$-Cit for 48 hr caused production of ROS (Fig. 2, lane 4).

\section{$R T-P C R$ of NOS}

RT-PCR showed the presence of nNOS in NB9 (Fig. 3). iNOS was detected faintly in the cells, but eNOS was not detected. The expression of nNOS did not change upon treatment with various concentrations of L-Arg at 23 cycles of PCR.

\section{DNA Damage}

Flow cytometric analysis showed a $14 \%$ increase in the relative intensity at the sub-Gl phase in NB9 incubated with $2 \mathrm{mM} \mathrm{L}$-Arg for $48 \mathrm{hr}$ and an $18 \%$ decrease at the G2-M phase. This suggests that a high concentration of L-Arg induces DNA damage and arrest at the Gl phase in NB9 (Fig. 4, right panel).
(3)

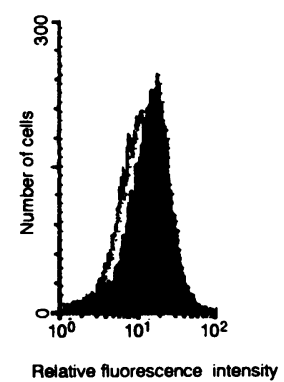

(3)

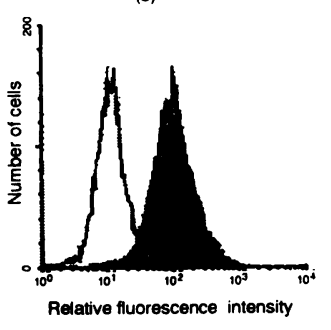

(4)

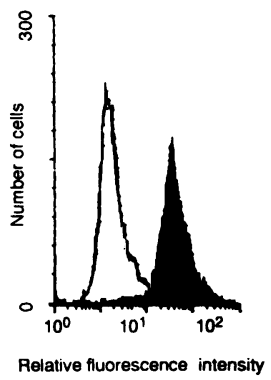

(4)

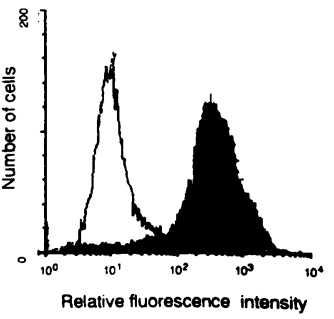

estimated as fluorescence intensity. (B) NB9 was incubated for $48 \mathrm{hr}$ as described above, then with 2 $\mu \mathrm{M} \mathrm{DHR}$ for $30 \mathrm{~min}$ at $37^{\circ} \mathrm{C}$ and the formation of rhodamine 123 was estimated flow cytometrically as for DCFH-DA. The histograms represent the number of cells as a function of relative fluorescence intensity. Data are representative of three experiments with similar results.

\section{Transcriptional Regulation}

Nucleic factor- $\kappa \mathrm{B}(\mathrm{NF}-\kappa \mathrm{B})$ and AP-1 are activated in response to oxidative stress. In a preliminary study, no change in the activity of NF- $\kappa \mathrm{B}$ was observed (data not shown). An electrophoretic mobility shift assay was carried out on the DNA-binding activity of AP-1. Figure 5 shows the results of the activation of AP-1 on an electrophoretic mobility shift assay conducted by incubating NB9 with $2 \mathrm{mM} \mathrm{L}$-Arg for $48 \mathrm{hr}$. The activity of AP-1 was stimulated 1.5 -fold by $2 \mathrm{mM}$ L-Arg (Fig. 5, lane 5). The activity of AP-1 was not stimulated by $50 \mu \mathrm{M}$ L-Arg (Fig. 5, lane 4). This result suggests that the DNA-binding activity of AP-l is stimulated by oxidative stress produced by a high concentration of L-Arg.

\section{Discussion}

In the nervous system, nNOS is localized to discrete populations of neurons in the cerebellum, olfactory bulb, hippocampus, cortex, striatum, basal forebrain, and brain stem $(16,17)$. NOS is 

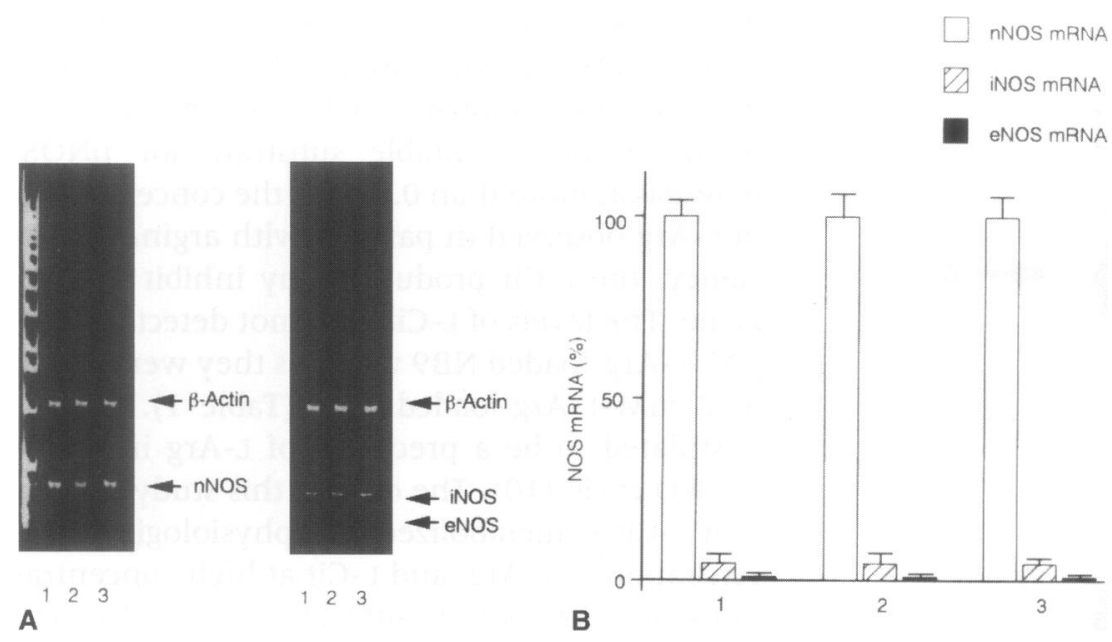
Fig. 3. Expression of NOS mRNA. Presence of NOS isoform mRNA was esti- mated by RT-PCR. (A) NB9 was incubated with $50 \mu \mathrm{M}$ L-Arg (lane 1), $1 \mathrm{mM} \mathrm{L-Arg}$ (lane 2), and $2 \mathrm{mM}$ L-Arg (lane 3), then the expression of NOS isoforms was esti- mated as described in Mate- rials and Methods. (B) The data were obtained as rela- tive intensity $(\%)$. Lanes cor- respond to those in $\mathrm{A}$. The expression of NOS isoforms was corrected with that of $\beta$-actin.

also concentrated in the posterior pituitary gland, in the supraoptic and paraventricular hypothalamic nuclei, and in discrete ganglion cells of the adrenal medulla (16). Greenwood et al. reported that the expression of nNOS is relatively high in the cerebellum and approximately half of that in the cerebral cortex (18). The widespread cellular localization of nNOS and the short halflife and diffusion properties of NO have led to speculation that NO plays a key role in nervous system morphogenesis and synaptic plasticity (19). During development, NO may influence activity-dependent synaptic pruning, apoptosis, and the establishment of the columnar reorganization of the cortex (20).

NOS is a complex dioxygenase enzyme containing a C-terminal domain homologous to cytochrome p-450 reductase (21). Besides synthesizing NO from L-Arg, NOS can generate oxygen-derived ROS such as superoxide or hydrogenperoxide when the substrate L-Arg is suboptimal (22). Pou et al. (23) were the first to report a radical, superoxide generated by purified nNOS from rat in an NADPH-dependent manner in L-Arg-deficient medium using ESR. Culcasi et al. (24) speculated that superoxide is induced via activation of NOS by glutamate receptor-mediated signals in L-Arg-depleted neurons and that the superoxide produced by NOS is a weak but significant cell death signal.

In the present study, the production of ROS was detected in neurological cells exposed to a 20-molar excess of L-Arg. Synthesis of ROS was evaluated by flow cytometric analysis, a method not specific for superoxide. However, the production of ROS was abolished by the treatment of NB9 with L-NAME, a NOS blocker (Fig. 2), suggesting that ROS in NB9 loaded with a high concentration of L-Arg could be produced by NOS. The presence of iNOS has been reported in non-neuronal cells, such as glial cells, in the brain (25). And in this study, the expression of
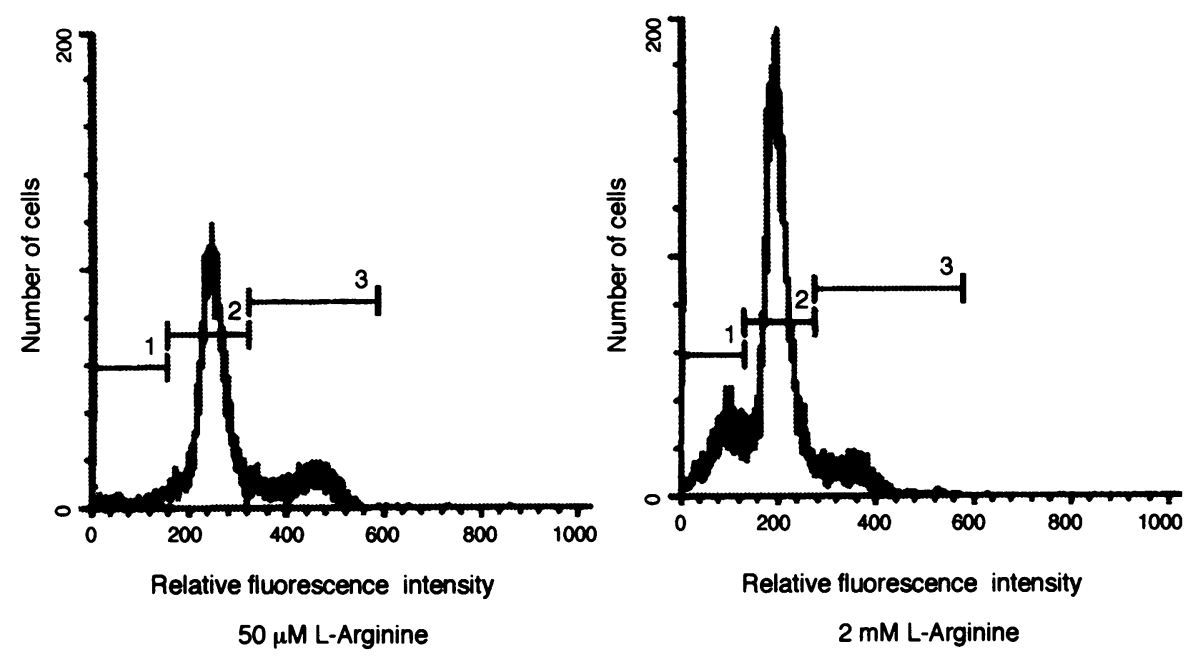

Fig. 4. DNA damage by L-Arg. DNA damage in LArg-loaded NB9 was determined by estimating the formation of sub-Gl phase of DNA (1), and changes in the number of Gl (2) and G2-M (3) phases. DNA content per nucleus was evaluated in a FACScan flow cytometer after staining nuclei with propidium iodide. Left panel, 50 $\mu \mathrm{M}$ L-Arg; right panel, $2 \mathrm{mM}$ L-Arg. 


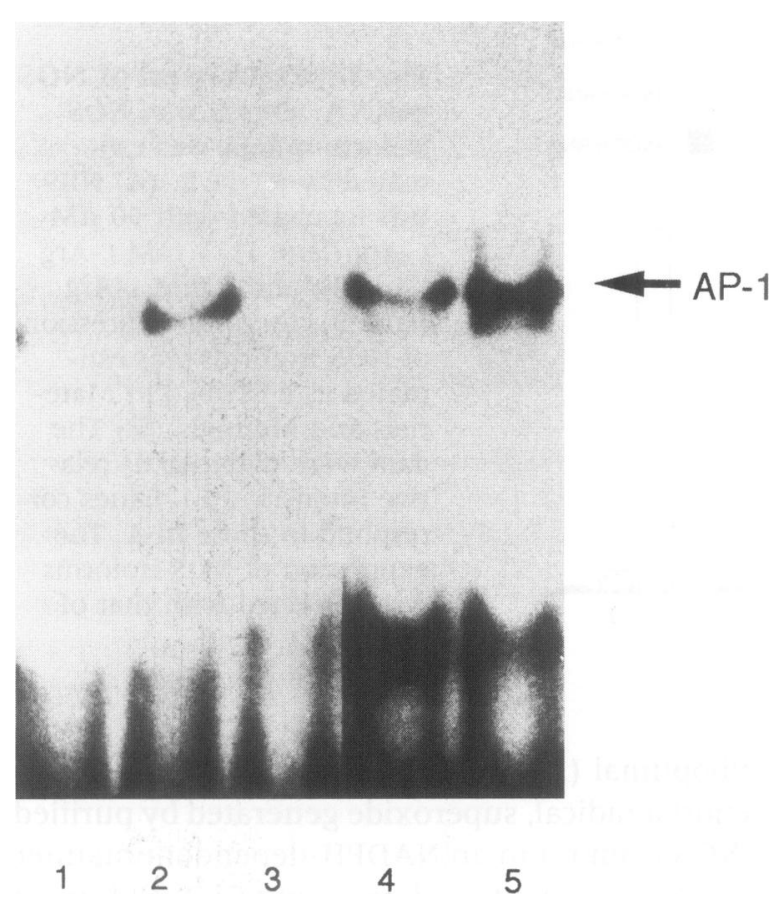

Fig. 5. Electrophoretic mobility shift assay of AP-1. The DNA-binding activity of AP-1 was estimated using an electrophoretic mobility shift assay. NB9 was incubated with $50 \mu \mathrm{M}$ or $2 \mathrm{mM}$ L-Arg for $48 \mathrm{hr}$. DNA extracts from each of these cells were incubated with an AP-1-specific ${ }^{32} \mathrm{P}$-oligonucleotide for $20 \mathrm{~min}$ and then loaded on a $6 \%$ nondenaturing polyacrylamide gel and subjected to electrophoresis in $25 \mathrm{mM}$ Tris, $22.5 \mathrm{mM}$ borate, and $0.25 \mathrm{mM}$ EDTA, pH 8.0. The DNA binding activity of the extracts was quantified by estimating the amount of the ${ }^{32} \mathrm{P}$-labeled AP-1. Lane 1, free probe; lane 2, Hela cell extracts as a positive control; lane 3, a 100fold excess of unlabeled probe as a specificity control; lane 4, $50 \mu \mathrm{M}$ L-Arg; lane 5, 2 mM L-Arg.

iNOS mRNA was not apparent in the absence of cytokines or other stimulants in the medium. nNOS but not eNOS mRNA was detected in NB9 and IMR 32 concomitantly with the levels of NO (Fig. 3), suggesting that nNOS is involved in the formation of ROS.

The kinetics of nNOS in NB9 were studied. The apparent $\mathrm{K}_{\mathrm{m}}$ value of nNOS for L-Arg with $8.4 \mu \mathrm{M}$ was in agreement with previous reports on the characteristics of human brain NOS $(26,27)$. This is the first report to show that L-Cit inhibits NOS activity and produces ROS in a concentration-dependent manner. A possible mechanism by which ROS are produced in NB9 at a high concentration of L-Arg is as follows: an excess of substrate, L-Arg, produces sufficient amounts of L-Cit. L-Cit binds to the L-Arg binding site of NOS and inhibits the NO synthesis, and nNOS functions as a NADPH oxidase to pro- duce superoxide as observed in L-Arg-depleted cells (26-28). At a physiological concentration of plasma L-Arg (approximately $50 \mu \mathrm{M}$ ) (4), L-Cit seems to be a suitable substrate for nNOS, whereas at more than $0.5 \mathrm{mM}$, the concentration of L-Arg observed in patients with arginase deficiency, the L-Cit produced may inhibit the enzyme. The levels of L-Cit were not detected in 50 $\mu \mathrm{M}-\mathrm{L}-\mathrm{Arg}$-loaded NB9 whereas they were found in $2 \mathrm{mM}$-L-Arg-loaded NB9 (Table 1). L-Cit is postulated to be a precursor of L-Arg in the LCit-NO cycle (10). The data in this study suggest that L-Cit is metabolized at a physiological concentration of L-Arg, and L-Cit at high concentrations of L-Arg is not sufficiently utilized in the L-Cit-NO cycle.

Since the levels of L-Arg and L-Cit in the cells were expressed in terms of contents, it is hard to explain from the results of the kinetic study how the formation of L-Cit alone suppresses NOS activity contributing to neurotoxicity in L-Argloaded cells. In general, it is important to distinguish NOS activity in broken cells that is caused by various compounds from that which may occur in whole cells. L-Cit may decrease the viability of the cells in addition to inhibiting NOS activity. On the other hand, ROS formed by L-Cit [Fig. 2 (4)], may be involved in cell damage by L-Cit. Protection of neurotoxicity by antioxidants has been reported (28), which strongly suggests that chronic formation of ROS contributes to neurotoxicity. The production of superoxide in L-Arg-loaded cells could explain the neurological cell injury in argininemia.

AP-1 is a sequence-specific transcriptional activator composed of members of the Jun and Fos families (29). These proteins associate to form a variety of homo- and heterodimers that bind to a common site. AP- 1 is activated by oxidative stress, phorbor ester 12-0-tetradecanoylphorbol-13-acetate, growth factors, cytokines, and UV irradiation (29). Gel-shift assay has shown that AP-1-DNA binding activity is stimulated in L-Arg-loaded NB9 (Fig. 5), suggesting that ROS produced by NOS cause oxidative stress in the cells. In conclusion, neurotoxicity in argininemia may be induced through a mechanism in which ROS are produced by NOS in neurological cells.

\section{Acknowledgments}

This work was supported in part by a grant-inaid from the Ministry of Education, Science and Culture of Japan and The Chiyoda Life Social Welfare Foundation. 


\section{References}

1. Brusilow SW, Horwich AL. (1989) Urea cycle enzymes. In: Scriver CR, Sly WAS, Beaudet AL, Valle $D$ (eds). The Metabolic Basis of Inherited Disease. Mc-Graw-Hill, New York, pp. 629-663.

2. Uchino $T$, Snyderman SE, Lambert $M$, et al. (1995) Molecular basis of phenotypic variation in patients with argininemia. Hum. Genet. 96: 255260.

3. Marescau B, De Deyn PP, Lowenthal A, et al. (1990) Guanidino compound analysis as a complementary diagnostic parameter for hyperargininemia: Follow-up of guanidino compound levels during therapy. Pediatr. Res. 27: 297-303.

4. Haraguchi $Y$, Takiguchi M, Amaya Y, Kawamoto S, Matsuda I, Mori M. (1987) Molecular cloning and nucleotide sequence of cDNA for human liver arginase. Proc. Natl. Acad. Sci. U.S.A. 84: 412-415.

5. Takiguchi $M$, Haraguchi $Y$, Mori $M$. (1988) Human liver-type arginase gene: Structure of the gene and analysis of the promoter region. $\mathrm{Nucl}$. Acids Res. 16: 8789-8802.

6. Sparkes RS, Dizikes GJ, Klisak I, et al. (1986) The gene for human liver arginase (ARGl) is assigned to chromosome band 6q23. Am. J. Hum. Genet. 39: 186-193.

7. Haraguchi Y, Aparicio JM, Takiguchi $M$, et al. (1990) Molecular basis of argininemia. Identification of two discrete frame-shift deletions in the liver-type arginase gene. J. Clin. Invest. 86: 347350.

8. Uchino $\mathrm{T}$, Haraguchi $\mathrm{Y}$, Aparicio JM, et al. (1992) Three novel mutations in the liver-type arginase gene in three unrelated Japanese patients with argininemia. Am. J. Hum. Genet. 51: 1406-1412.

9. Bredt DS, Ferris CD, Snyder SH. (1992) Nitric oxide synthase regulatory sites. Phosphorylation by cyclic AMP-dependent protein kinase, protein kinase $C$, and calcium/calmodulin protein kinase: Identification of flavin and calmodulin binding sites. J. Biol. Chem. 267: 10976-10981.

10. Yu Y, Terada K, Nagataki A, Takiguchi M, Mori M. (1995) Preparation of recombinant argininosuccinate synthetase and argininosuccinate lyase: Expression of the enzymes in rat tissues. J. Biochem. 117: 952-957.

11. Urata Y, Yamamoto H, Goto S, et al. (1996) Long exposure to high glucose concentration impairs the responsive expression of $\gamma$-glutamylcysteine synthetase by interleukin- $1 \beta$ and tumor necrosis factor $\alpha$ in mouse endothelial cells. J. Biol. Chem. 271: 15146-15152.

12. Sen R, Baltimore D. (1986) Multiple nuclear factors interact with the immunoglobulin enhancer sequences. Cell 46: 705-716.

13. Galea E, Feinstein DL, Reis DJ. (1992) Induction of calcium-independent nitric oxide synthase ac- tivity in primary rat glial cultures. Proc. Natl. Acad. Sci. U.S.A. 89: 10945-10949.

14. Bass DA, Parce JW, Dechatelet LR, Szejda P, Seeds MC, Thomas M. (1983) Flow cytometric studies of oxidative product formation by neutrophils: a graded response to membrane stimulation. $\mathrm{J}$. Immunol. 130: 1910-1917.

15. Gong J, Traganos F, Darzynkiewicz Z. (1994) A selective procedure for DNA extraction from apoptotic cells applicable for gel electrophoresis and flow cytometry. Anal. Biochem. 218: 314319.

16. Bredt DS, Hwang PM, Snyder SH. (1990) Localization of nitric oxide synthase indicating a neural role for nitric oxide. Nature 347: 768770.

17. Dawson TM, Bredt DS, Fotuhi M, Hwang PM, Snyder SH. (1991) Nitric oxide synthase and neuronal NADPH diaphorase are identical in brain and peripheral tissues. Proc. Natl. Acad. Sci. U.S.A. 88: 7797-7801.

18. Greenwood MT, Guo Y, Kumar U, Beauséjours S, Hussain SNA. (1997) Distribution of protein inhibitor of neuronal nitric oxide synthase in rat brain. Biochm. Biophys. Res. Commun. 238: 617621.

19. Huang PL, Dawson TM, Bredt DS, Snyder SH, Fishman MC. (1993) Targeted disruption of the neuronal nitric oxide synthase gene. Cell 75: 1273-1286.

20. Gally JA, Montague PR, Reeke GN Jr, Edelman GM. (1990) The NO hypothesis: possible effects of a short-lived, rapidly diffusible signal in the development and function of the nervous system. Proc. Natl. Acad. Sci. U.S.A. 87: 3547-3551.

21. Bredt DS, Hwang PM, Glatt CF, Lowenstein C, Reed RR, Snyder SH. (1991) Cloned and expressed nitric oxide synthase structurally resembles cytochrome P-450 reductase. Nature 351: 714-718.

22. Heinzel B, John M, Klatt P, Bohme E, Mayer B. (1992) $\mathrm{Ca}^{2+} /$ calmodulin-dependent formation of hydrogen peroxide by brain nitric oxide synthase. Biochem. J. 281: 627-630.

23. Pou S, Pou WAS, Bredt DS, Snyder SH, Rosen GM. (1992) Generation of superoxide by purified brain nitric oxide synthase. J. Biol. Chem. 267: 24173-24176.

24. Culcasi M, Lafon-Cazal M, Pietri S, Bockaert J. (1994) Glutamate receptors induce a burst of superoxide via activation of nitric oxide synthase in arginine-depleted neurons. J. Biol. Chem. 269: 12589-12593.

25. Simmons ML, Murphy S. (1992) Induction of nitric oxide synthase in glial cells. $J$. Neurochem. 59: 897-905.

26. Jiang K, Kim S, Murphy S, Song D, Pastuszko A. (1996) Effect of hypoxia and reoxygenation on regional activity of nitric oxide synthase in brain of newborn piglets. Neurosci. Lett. 206: 199-203. 
27. Hall AV, Antoniou H, Wang Y, et al. (1994) Structural organization of the human neuronal nitric oxide synthase gene (NOS1). J. Biol. Chem. 269: 33082-33090.

28. Iwanaga $M$, Mori $K$, Iida $T$, et al. (1998) Nuclear factor kappa $\mathrm{b}$ dependent induction of gamma glutamylcysteine synthetase by ionizing radiation in T98G human glioblastoma cells. Free Radic. Biol. Med. 24: 1256-1258.

29. Karin M. (1995) The regulation of AP-1 activity by mitogen-activated protein kinases. J. Biol. Chem. 270: 16483-16486. 